九州大学学術情報リポジトリ

Kyushu University Institutional Repository

\title{
Modification of Tryptophan Residues of Plant Class III Chitinases Involved in Enzyme Activity
}

\section{Ishiguro, Masatsune}

Laboratory of Protein Chemistry and Engineering, Department of Genetic Resources Technology, Faculty of Agriculture, Kyushu University

Yamagami, Takeshi

Laboratory of Protein Chemistry and Engineering, Department of Genetic Resources Technology, Faculty of Agriculture, Kyushu University

Tanigawa, Miho

Laboratory of Protein Chemistry and Engineering, Department of Genetic Resources Technology, Graduate School of Bioresource and Bioenvironmental Sciences, Kyushu University

Tsutsumi, Kazuki

Laboratory of Protein Chemistry and Engineering, Department of Genetic Resources Technology, Graduate School of Bioresource and Bioenvironmental Sciences, Kyushu University

他

https://doi.org/10.5109/24436

出版情報: 九州大学大学院農学研究院紀要. 46 (1)，pp. 243-250，2001-10-30. Kyushu University バージョン：

権利関係 : 


\title{
Modification of Tryptophan Residues of Plant Class III Chitinases Involved in Enzyme Activity
}

\author{
Masatsune ISHIGURO**, Takeshi YAMAGAMI, Miho TANIGAWA*, Kazuki \\ TSUTSUMI*, Gunki FUNATSU, Takayuki OHNUMA* and Yoichi ASO
}

\author{
Laboratory of Protein Chemistry \& Engineering, Department of Genetic Resources Technology, \\ Faculty of Agriculture, Kyushu University, Fukuoka 812-8581, Japan \\ (Received June 29, 2001 and accepled July 11, 2001)
}

\begin{abstract}
Chemical modification of tulip bulb chitinase-1 (TBC-1) and pokeweed leaf chitinase (PLC-B) with $\mathrm{N}$-bromosuccinimide (NBS) suggested the involvement of tryptophan residue (s) in the activity. In the case of $\mathrm{TBC}-1$, at $\mathrm{pH} 4.0$, about 1 mol of tryptophan residues out of $4 \mathrm{~mol}$ was oxidized with $5 \mathrm{~mol}$ of NBS per mol of TBC-1 and all $4 \mathrm{~mol}$ of tryptophan residues were oxidized with $15 \mathrm{~mol}$ of NBS. At pH 4.5 , about $3 \mathrm{~mol}$ of tryptophan were finally oxidized although the oxidation rate of the first tryptophan residue was same as at $\mathrm{pH} 4.0$. In both cases, the oxidation of $1 \mathrm{~mol}$ of tryptophan residues caused $85 \%$ activity loss. Analysis of the oxytryptophan-containing peptides afforded to identify that $\operatorname{Trp} 172$ and $\operatorname{Trp} 255$ were those which reacted first with NBS at $\mathrm{pH} 4.0$.

When PLC-B was reacted with 16-folds molar of NBS at $\mathrm{pH} 4.0$, all seven tryptophan residues were oxidized with a concomitant decrease of chitinase activity. Oxidized tryptophan residues were also determined as those at positions of 165 and 256 in PLC-B. From these results, it was inferred that the rapidly oxidized tryptophan residues in plant class II chhitinases were involved in their chitinase activity.
\end{abstract}

\section{INTRODUCTION}

Chitinases (EC 3.2.1.14) are enzymes catalyzing the hydrolysis of chitin, a $\beta$ -1,4-linked homopolymer of N-acetylglucosamine (GlcNAc) and are considered to be self-defense-related proteins for protection against fungal pathogens (Schlumbaum et al., 1986, Broekaert et al., 1988, Stintzi et al., 1993, Gooday, 1999). Five classes of plant chitinases have been proposed on the basis of the amino acid sequence (Henrissat and Bairoch, 1993). Class I chitinase consists of a chitin-binding domain and a catalytic domain linked with a linker peptide; class II chitinase shows sequence similarity to the class I chitinase but lacks the chitin-binding domain; class III chitinase shows no sequence similarity to class I nor II chitinase but has distant sequence similarity to bacterial and fungal chitinases; class IV chitinase shows sequence similarity to the class I chitinase but it is smaller due to four deletions; and class $\mathrm{V}$ chitinase shows distant sequence similarity to bacterial and fungal chitinases as class III chitinase does, but it is larger than class III chitinase.

We previously isolated two bulb chitinases, GBC-a from gladiolus (Gladiolus gan-

\footnotetext{
* Laboratory of Protein Chemistry \& Engineering, Department of Genetic Resources Technology, Graduate School of Bioresource and Bioenvironmental Sciences, Kyushu University, Fukuoka 812-8581, Japan

** Corresponding author: Fax number: 092-642-3051, E-mail: ishiguro@agr.kyushu-u.ac.jp
} 
davensis) (Yamagami et al., 1997) and TBC-1 from tulip (Tulipa bakeri) (Yamagami et $a l ., 1998 \mathrm{~b}$ ), and characterized their enzymatic properties and amino acid sequences (Yamagami et al., 1998a, Yamagami and Ishiguro, 1998) to find that bulb chitinase belongs to the class III chitinase. We later cloned cDNA of TBC-1, sequenced and expressed it in E. coli cells (Yamagami et al., 2000). We also isolated two plant chitinases from the pokeweed leaves (PLC-A and -B) and characterized (Ohta et al., 1995). From their amino acid sequences, PLC-A belongs to class II (Yamagami et al., 1998c) and PLC-B to class III (Tanigawa et al., 1995), respectively. However, there are major differences in properties between the bulb chitinases and so far reported plant class III chitinases: 1) bulb chitinase had no disulfide bond but plant class III had conserved three disulfide bonds (Tanigawa et al., 1995); 2) bulb chitinases had no lysozyme activity while hevamine (Jeckel et al., 1991) and PLC-B (Ohta et al., 1995) had; and 3) a hydrolysis of (GlcNAc) $)_{5}$ yielded (GlcNAc) $)_{2}$ and (GlcNAc) $)_{3}$ by bulb chitinases and GlcNAc and (GlcNAc) ${ }_{4}$ by PLC-B (Ohta et al., 1995).

In this paper, we have exploited a role of tryptophan residue of plant class III chitinase (TBC-1 and PLC-B) by chemical modification with $\mathrm{N}$-bromosuccinimide. We have also determined their positions and discussed activity and structure relationship of class III chitinase.

\section{MATERIALS AND METHODS}

\section{Materials.}

TBC-1 was purified from tulip (Tulipa bakeri) bulbs as described (Yamagami et al., 1998b), and PLC-B from the leaves of pokeweed (Phytolacca americana) as reported (Ohta et al., 1995). N-Bromosuccinimide (NBS) was purchased from Wako Pure Chemicals and recrystallized from deionized water before use. Lysylendopeptidase and thermolysin were from Wako Pure Chemicals, and TLCK-chymotrypsin from Sigma Chemical Co.

\section{Modification of Class III plant chitinases.}

Modification of TBC-1 and PLC-B with NBS was done at $15^{\circ} \mathrm{C}$ as reported previously for class I and II chitinases (RSC-a and -c) (Yamagami and Funatsu, 1996 and 1997), which was essentially based on the method described by Spande et al. (Spande et al., 1966). Ten $\mu \mathrm{l}$ of $2.8 \mathrm{mM}$ NBS solution in $0.1 \mathrm{M}$ sodium acetate buffer of the desired $\mathrm{pH}$ was added to $2 \mathrm{ml}$ of protein solution (each $0.4 \mathrm{mg}$ of $\mathrm{TBC}-1$ or PLC-B/ml of the same buffer) in a quartz cell with stirring. After $1 \mathrm{~min}$, the UV absorption spectrum of the reaction mixture was recorded using a Hitachi U-3210 spectrophotometer and a decrease in absorbance at $280 \mathrm{~nm}$ was measured. This procedure was repeated until the decrease at $280 \mathrm{~nm}$ ceased. The number of the tryptophan residue oxidized was calculated from the decrease in the absorbance at $280 \mathrm{~nm}$ (Spande and Witkop, 1967).

\section{Chitinase activity measurement}

The routine assessment of chitinase activity was performed colorimetrically with glycolchitin as a substrate. Enzymatic reaction was monitored by an increase in the reducing sugar according to the method of Imoto and Yagishita (Imoto and Yagishita, 
1971). Ten $\mu \mathrm{l}$ of the enzyme solution (1.6 pmol) was added to $500 \mu \mathrm{l}$ of $0.2 \%(\mathrm{w} / \mathrm{v})$ glycolchitin solution in $0.1 \mathrm{M}$ sodium acetate buffer, $\mathrm{pH} 5.0$. After incubation at $37^{\circ} \mathrm{C}$ for $15 \mathrm{~min}$, the reducing power of the mixture was measured with ferri-ferrocyanide reagent. One unit of activity was defined as the enzyme activity that produced $1 \mu \mathrm{mol}$ of GlcNAc per min at $37^{\circ} \mathrm{C}$. Concentrations of TBC-1, NBS-oxidized TBC-1, PLC-B and NBS-oxidized PLC-B were determined by amino acid analysis after acid hydrolysis.

\section{Identification of oxidized tryptophan residues of TBC-1 or PLC-B}

To identify rapidly oxidized tryptophan residue (s) in TBC-1 or PLC-B, TBC-1 or PLC-B was separately reacted with NBS under the conditions where about $85 \%$ of activity was lost. The reaction mixtures were dialyzed and lyophilized. Reduction and carboxymethylation, proteolytic digestion, fractionation of peptides were carried out as described previously (Yamagami and Funatsu, 1996 and 1997). Determination of peptides by UV spectrum, amino acid analysis and $\mathrm{N}$-terminal sequence analysis afforded the identification of oxidized tryptophan residue (s).

\section{RESULTS}

\section{NBS-oxidation of TBC-1}

When TBC-1 was treated with NBS at pH 4.0, as shown in Fig. 1, 3.9 of 4 tryptophan

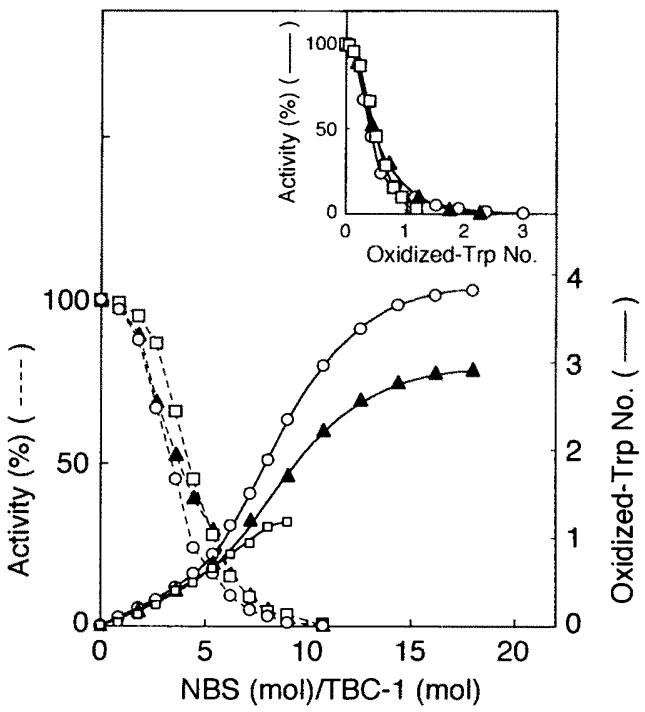

Fig. 1. Effects of NBS-oxidation of Tryptophan Residues on Chitinase Activity of TBC-1 TBC-1 was oxidized with NBS at $\mathrm{pH} 4.0(\mathrm{O}), \mathrm{pH} 4.5(\boldsymbol{\Delta})$ and $\mathrm{pH} 5.0$ (口). The number of tryptophan residues oxidized was calculated spectrophotometrically, based on the molar absorbance coefficient of $5,500 \mathrm{M}^{1} \cdot \mathrm{cm}^{-1}$ at $280 \mathrm{~nm}(-)$. Chitinase activity was measured at $\mathrm{pH} 5.0$ with glycolchitin as a substrate and the activity of native $\mathrm{TBC}-1$ was taken to be $100 \%(\cdots)$. In the inset, activity vs oxidized tryptophan residues was replotted. 
residues in TBC-1 were oxidized with $18 \mathrm{~mol}$ of NBS per mol of TBC-1. The reactivity of tryptophan residues toward NBS decreased with the increase in $\mathrm{pH}$. At pHs 4.5 and 5.0, 3.0 and 1.2 tryptophan residues were oxidized with 18 and $9 \mathrm{~mol}$ of NBS, respectively. Chitinase activity of TBC-1 toward glycolchitin was lost by oxidation of one tryptophan residue in any cases (Fig. 1, inset). These results suggested that one tryptophan residue oxidized first was involved in the chitinase activity.

\section{Identification of the tryptophan residue oxidized first in $\mathbf{T B C}-1$}

The tryptophan residue oxidized first was identified by using $1 \mathrm{~W}$-oxid-TBC-1 prepared by treatment with $8 \mathrm{~mol}$ of NBS at pH 5.0. 1W-oxid-TBC-1 was digested with lysylendopeptidase followed by chymotrypsin. Lyophilized digest was dissolved in $5 \mathrm{mM}$ potassium phosphate buffer, $\mathrm{pH} 6.0$, and separated into the soluble (Cs) and the pellet (Cp) fractions, and then the Cp fraction was further digested with thermolysin (CTs fraction). The resulting peptides were first separated by reverse-phase HPLC on a YMC-Gel C4 column using a phosphate acetonitrile elution system, and then purified by reverse-phase HPLC on YMC-Gel C18 column using a trifluoroacetic acid-acetonitrile elution system. From the UV-absorption spectra of the peptides, five and two peptides containing oxytryptophan residue were obtained from the Cs and CTs fractions, respectively. Amino acid compositions and N-terminal sequences of these peptides are shown in Table 1. From these results, it was seen that Trp172 and Trp251 of TBC-1 were equally oxidized by NBS.

Table 1. Amino acid compositions of peptides containing oxytryptophan residue

\begin{tabular}{|c|c|c|c|c|c|c|c|}
\hline Peptide & Cs2 & Cs3a & Cs4 & Cs5 & Cs6 & CTsla & CTs3 \\
\hline Asp & & \multirow{7}{*}{$2.12(2)$} & \multirow{7}{*}{$2.21(2)$} & $2.83(3)$ & $1.88(2)$ & & \multirow{7}{*}{$1.13(1)$} \\
\hline Glu & & & & & & & \\
\hline Ser & & & & $1.35(1)$ & $1.26(1)$ & & \\
\hline Gly & & & & & & & \\
\hline His & & & & & & & \\
\hline Arg & & & & & & & \\
\hline Thr & & & & & & & \\
\hline $\mathrm{Ala}$ & & \multirow[t]{7}{*}{$2.08(2)$} & \multirow[t]{7}{*}{$1.05(1)$} & \multirow[t]{3}{*}{$1.18(1)$} & \multirow[t]{3}{*}{$1.15(1)$} & \multirow[t]{3}{*}{$0.77(1)$} & \multirow[t]{7}{*}{$0.43(0)$} \\
\hline Pro & & & & & & & \\
\hline Tyr & & & & & & & \\
\hline Val & \multirow[t]{4}{*}{$1.00(1)$} & & & \multirow[t]{4}{*}{$1.00(1)$} & \multirow[t]{4}{*}{$1.00(1)$} & \multirow[t]{4}{*}{$1.00(1)$} & \\
\hline Met & & & & & & & \\
\hline Cys & & & & & & & \\
\hline lle & & & & & & & \\
\hline Leu & & $0.68(1)$ & $0.95(1)$ & \multicolumn{2}{|l|}{$0.60(1)$} & & \multirow[t]{2}{*}{$0.94(1)$} \\
\hline Phe & \multirow{3}{*}{$+(1)$} & & & $0.62(1)$ & & & \\
\hline $\operatorname{Trp}$ & & \multirow[t]{2}{*}{$+(1)$} & $+(1)$ & \multirow[t]{2}{*}{$+(1)$} & \multirow[t]{2}{*}{$+(1)$} & \multirow[t]{2}{*}{$+(1)$} & $+(1)$ \\
\hline Lys & & & $1.00(1)$ & & & & $1.00(1)$ \\
\hline Yield ( $\mathrm{n} \mathrm{mol}$ ) & 3 & 0.5 & 2.3 & 1.2 & 1.5 & 2.2 & 0.9 \\
\hline $\mathrm{N}$-terminal & V & Q & Q & $\mathrm{F}$ & V & $\mathrm{V}$ & A \\
\hline Corresponding sequence & VW & QALWEK & QALWEK & FVWSADDSL & VWSADD & VW & ALWEK \\
\hline Position of Trp in TBC-1 & 251 & 172 & 172 & 251 & 251 & 251 & 172 \\
\hline
\end{tabular}




\section{NBS-oxidation of PLC-B}

When PLC-B was treated with NBS, as shown in Fig. 2, tryptophan residue (s) were oxidized linearly with the increasing amount of NBS and ended up with all seven tryptophan residues oxidized with 16 -folds molar NBS. The modified PLC-B in which $2 \mathrm{~mol}$ of $7 \mathrm{~mol}$ of tryptophan residues were oxidized, showed almost complete loss of chitinase activity at $\mathrm{pH} 7.0$ and $80 \%$ loss at $\mathrm{pH} 3.5$ while oxidation of the third tryptophan residue resulted in the complete loss of activity at $\mathrm{pH} 3.5$ (Fig. 2, inset).

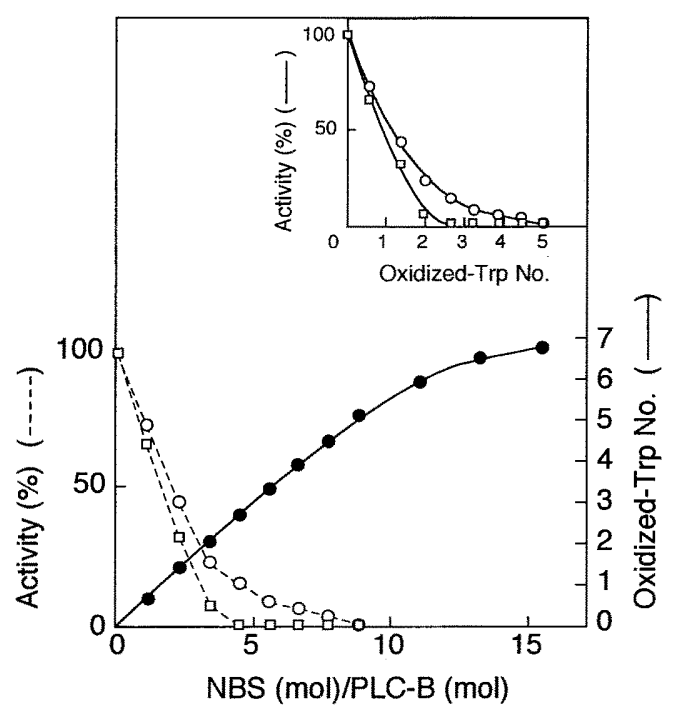

Fig. 2. Effects of NBS-oxidation of Tryptophan Residues on Chitinase Activity of PLC-B PLC-B was oxidized with NBS at $\mathrm{pH} 4.0(-)$ and the number of tryptophan residues oxidized was calculated spectrophotometrically, based on the molar absorbance coefficient of $5,500 \mathrm{M}^{-1} \cdot \mathrm{cm}^{-1}$ at $280 \mathrm{~nm}$. Chitinase activity was measured at $\mathrm{pH} 3.5(\bigcirc \cdots \bigcirc)$ and $\mathrm{pH} 7.0(\square \cdots \square)$ with glycolchitin as a substrate and the activity of native PLC-B was taken to be $100 \%$. In the inset, the numbers of oxidized tryptophan residues are plotted against chitinase activity at $\mathrm{pH}$ $3.5(\mathrm{O}-\mathrm{O})$ and $\mathrm{pH} 7.0(\square-\square)$.

\section{Identification of rapidly reacted tryptophan residues in PLC-B}

2W-oxi--PLC-B was reduced, carboxymethylated and subjected to proteolytic digestion with trypsin and thermolysin. Oxytryptophan-containing peptides were separated and analyzed as above demonstrating that oxidation by NBS occurred at Trp165 and Trp256 of PLC-B (Fig. 3).

\section{DISCUSSION}

Since Hayashi et al. first reported that Trp62 of lysozyme was oxidized with NBS with the concomitant 100\% loss of lysozyme activity (Hayashi et al., 1965), and Phillips et 


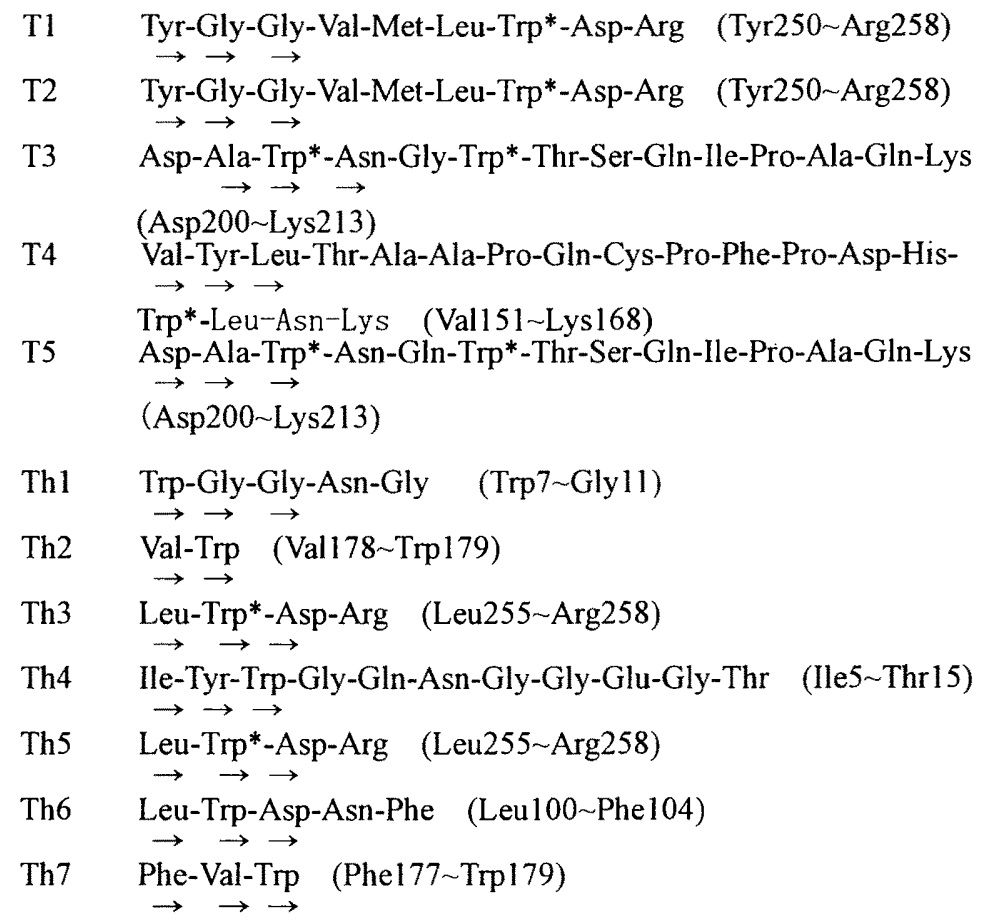

Fig. 3. Tryptophan-containing Peptides from RCM-2W-oxi-PLC,-B

$\mathrm{T}$ and Th represent peptides purified from tryptic and thermolytic digests, respectively, and Trp* indicates the presence of oxytryptophan. Arrows under the sequence show that amino acids were detcrmined by the Edman method. Description in the blankets are the corresponding positions in PLC-B.

al. later showed that Trp62 was really involved in substrate-binding in lysozyme by X-ray crystallographic study (Blake et al., 1965), NBS oxidation became one of the prominent methods to exploit amino acid residues that consist an active site in glycosyl hydrolases. With regard to the active site of the enzymes that hydrolyze glycolchitin and $\mathrm{N}$-acetylchitooligosaccharides, only lysozyme has been extensively investigated and little information concerning the active site of plant chitinases by chemical modification has been available. Yamagami and Funatsu examined the effects of chemical modifications on the activity of rye seed chitinase-c (RSC-c, class II) (Yamagami and Funatsu, 1996) and chitinase-a (RSC-a, class I) (Yamagami and Funatsu, 1997), and found that tryptophan and glutamic/aspartic acid residues might be involved in the activity. They, then, identified that Trp72 of RSC-c and Trp23 and Trp131 of RSC-a (Trp131 of RSC-a corresponds to Trp72 of RSC-c) are involved in substrate-binding.

With respect to class $\mathrm{II}$ chitinases, which have very distant similarity to bacterial and fungal chitinases but no sequence similarity to plant class I nor II chitinase, little information is available on the structure-activity relationship. TBC-1 has $15 \%$ similarity to hevamine and $14 \%$ to PLC-B, whereas PLC-B has $63 \%$ similarity to hevamine suggesting 


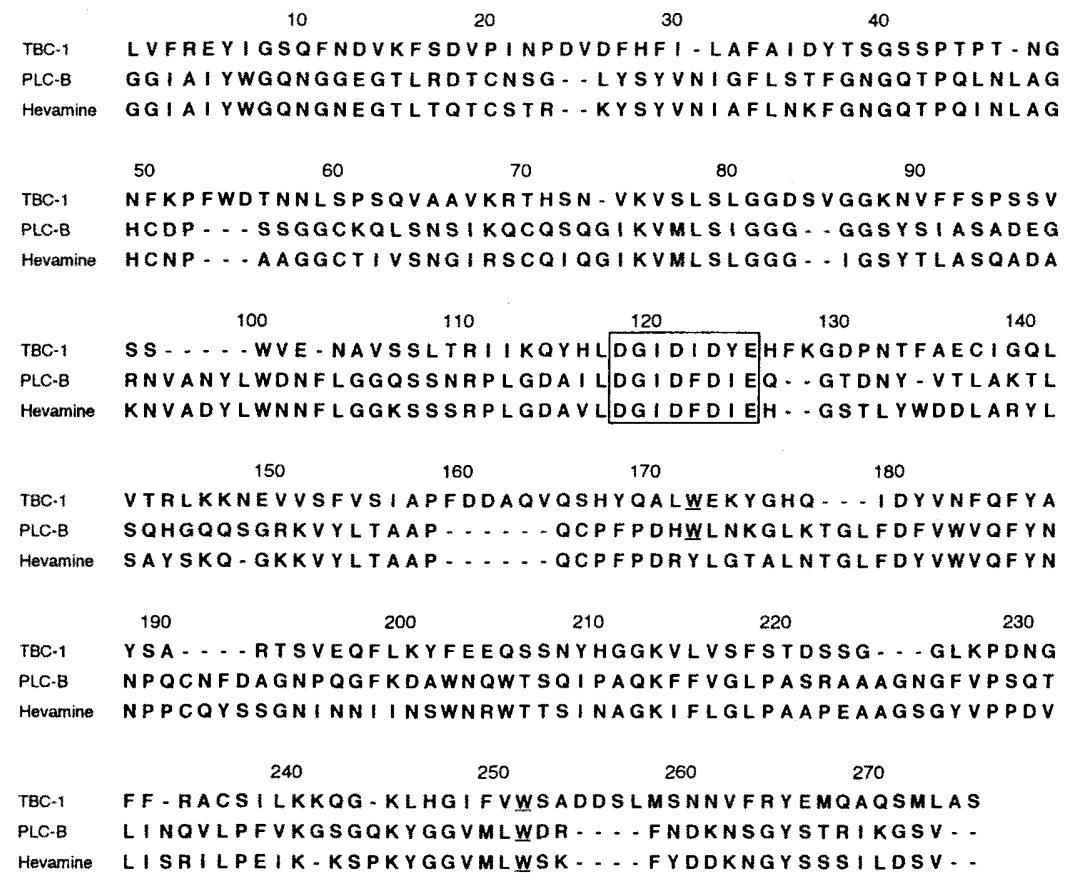

Fig. 4. Comparison of the Amino Acid Sequences of TBC-1, PLC-B and Hevamine.

Amino acid sequences of TBC-1 and PLC-B are aligned to compare with that of hevamine. Several gaps $(-)$ have been inserted to give an optimal alignment of the proteins. Amino acids homologous to the sequence known as the catalytic site of hevamine are shown in the box. The underlined residues indicate tryptophan residues rapidly oxidized with NBS.

that PLC-B belongs to the same class as hevamine (Fig. 4). We, therefore, undertook this modification study to see whether tryptophan residue (s) be also involved in the activity of class III chitinases. As a result, it was shown that oxidation reaction of tryptophan residue (s) in TBC-1 or PLC-B occurred as the amount of NBS increased, finally ended up all tryptophan residues oxidized as did in class I or class II chitinase. All tryptophan residues in TBC-1 and PLC-B seem to be located on the surface or the accessible part of the enzyme molecules. Both in TBC-1 and PLC-B, chitinase activity was lost when one or two tryptophan residues, respectively, were oxidized. From these results, it was inferred that most rapidly oxidized tryptophan residue (s) are responsible for the activity as in the cases of RSC-a (class I) and RSC-c (class II). Tryptophan residues that were rapidly oxidized were identified to be Trp 172 and Trp251 of TBC-1 and Trp165 and Trp256 of PLC-B. As shown in Fig. 4, these tryptophan residues are located at the same position in the alignment of both chitinases and hevamine. Of these residues, Trp251 of TBC-1 (or Trp256 of PLC-B) is conserved in hevamine, whose three dimensional structure was solved. In hevamine, tyrosine is located at the same position of Trp172 of TBC-1 and Trp165 of PLC-B. It is very interesting to investigate how the tryptophan residue (s) is 
involved in substrate-binding. Mutational analysis employing site-directed mutagenesis of these class III chitinases are being done.

\section{REFERENCES}

Blake, C. C. C. F., D. F. Koenig, G. A. Mair, A. C. T. North, D. C. Phillips and V. R. Sarma 1965 Structure of hen egg-white lysozyme: A three-dimensional Fourier synthesis at $2 \AA$ resolution. Nature, 206: $757-763$

Broekaert, W. F., J. Van Pariji, A. K. Allen and W. J. Peumans 1988 Comparison of some molecular, enzymatic, and antifungal properties of chitinases from thorn-apple, tobacco and wheat. Physiol. Mol. Plant Pathol., 33: 319-331

Gooday, G. W. 1999 Aggressive and defensive roles for chitinases. In "Chitin and Chitinases" ed. by P. Jollès, and R. A. A. Muzzarelli, Birkhauser, Basel, pp 157-169

Hayashi, K., T. Imoto and M. Funatsu 1965 The position of the active tryptophan residue in lysozyme. $J$. Biochem., 58: $227-235$

Henrissat, B. and A. Bairoch 1993 New families in the classification of glycosyl hydrolases based on amino acid sequence similarities. Biochem. $J$., 293: 781-788

Imoto, T. and K. Yagishita 1971 A simple activity measurement of lysozyme. Agric. Biol. Chem., 35: $1154 \cdots 1156$

Jeckel, P. A., J. B. H. Hartmann and J. Beintema 1991. The primary structure of hevamine, an enzyme with lysozyme/chitinase activity from Hevea brasiliensis. Eur. J. Biochem., 200: 123-130

Ohta, M., T. Yamagami and G. Funatsu 1995 Purification and characterization of two chitinases from the leaves of pokeweed (Phytolacca americana). Biosci. Biotechnol. Biochem., 59: 656-661

Schlumbaum, A., F. Mauxh, U. Vogeli and T. Boller 1986 Plant chitinases are potent inhibitors of fungal growth. Nature, 324: $365-367$

Spande, T. F., N. M. Green and B. Witkop 1966 The reactivity toward $N$-bromosuccinimide of tryptophan in enzymes, zymogens, and inhibited enzymes. Biochemistry: 5: 1926-1933

Spande, T. F. and B. Witkop, 1967 Determination of tryptophan content of proteins with N-bromosuccinimide. In "Methods in Enzymology", Vol. 11, ed. by C. H. W. Hirs, Academic Press, New York, pp. 498-506

Stintzi, A., T. Heitz, V. Prasad, S. Wiedermann-Merdinoglu, S. Kaufimann, P. Geoffroy, M. Legrand, and B. Fritig, 1993 Plant "pathogenesis-related" proteins and their role in defense against pathogens. Biochimie, 75: $687-706$

Tanigawa, M., T. Yamagami and G. Funatsu, 1995 The complete amino acid sequence of chitinase-B from the leaves of pokeweed (Phytolacca americana). Biosci. Biotechnol. Biochem., 59: 841-847

Yamagami, T. and G. Funatsu 1996 Identification of the tryptophan residue located at the substrate-binding site of rye seed chitinase-c. Biosci. Biotechnol. Biochem., 59: 1076-1081

Yamagami, T. and G. Funatsu, 1997 Involvement of Trp23 in the chitin-binding and of Trp131 in the chitinase activity of rye seed chitinase-a. Biosci. Biotechnol Biochem., 61: 1819-1825

Yamagami, T., Y. Mine, Y. Aso and M. Ishiguro 1997 Purification and characterization of two chitinase isoforms from the bulbs of gladiolus (Gladiolus gandavensis). Biosci. Biotechnol. Biochem., 61: $2140-2142$

Yamagami, T. and M. Ishiguro 1998 Complete amino acid sequences of chitinase-1 and -2 from bulbs of genus Tulipa. Biosci. Biotechnol. Biochem., 62: 1253-1257

Yamagami, T., Y. Mine and M. Ishiguro 1998a Complete amino acid sequence of chitinase-a from bulbs of gladiolus (Gladiolus gandavensis). Biosci. Biotechnol. Biochem., 62: 386-389

Yamagami, T., T. Taira, Y. Aso and M. Ishiguro 1998b Isolation and characterization of chitinase isoforms from the bulbs of four species of the genus Tulipa. Biosci. Biotechnol. Biochem., 62: 584-587

Yamagami, T., M. Tanigawa, M. Ishiguro and G. Funatsu $1998 \mathrm{c}$ Complete Amino Acid Sequence of Chitinase-A from Leaves of Pokeweed (Phytolacca americana). Biosci. Biotechnol. Biochem., 62 $825-828$

Yamagami, T., K. Tsutsumi and M. Ishiguro 2000 Cloning, sequencing, and expression of the tulip bulb chitinase-1 cDNA. Biosci. Biotechnol. Biochem., 64: 1394-1401 